\title{
ISLAMIC GROUP LENDING MODEL (GLM) AND FINANCIAL INCLUSION
}

\author{
Abrista Devi $^{1}$, Aam S. Rusydiana ${ }^{2}$
}

\begin{abstract}
* Affiliation:
${ }^{1}$ Lecturer at Ibnu Khaldun University; Research consultant at SMART Consulting. Email: abristasmart@gmail.com

${ }^{2}$ Researcher at Shariah Economic Applied Research and Training (SMART) Consulting. Email: aamsmart@gmail.com
\end{abstract}

\section{Abstract}

The lack of capital access from poor society to Indonesia banking is greater. These all are caused by poor society don't have enough collateral which is requested by bank officer to get loan. Non-bank financial institution is one of micro-financial institution which has covered all of poor society and also maximizing the existency of UMKM, include social model credit capital (GLM).

The aim of this study to see the form of Group Lending Model (GLM) and its' impact to their members social structure. This research also tries to give the solutions such as the first GLM development strategy in other to be more effective and efficient. The methods used are Structural Equation Modeling (SEM) and Interpretaive Structural Modeling (ISM).

Based on the measurement of some indicators there are the participation indext of society, society development, good repayment rate, good cross reporting, and penalty implications appropriate with the regulations. The results show that GLM programme, the society feel the differenciation from the economic and social condition between before and after following this programme. This is valuable invention for economic studies.

GLM development strategy are devided into 7 levels with its important elements are : the needy of similiarity fund access for all of financial institution. The needy of human resource quality development as the pioneer of group lending model, and the importance of inclusive financial to all financial system.

Keywords: Group Lending Model, Financial Inclusion, Structural Equation Model (SEM), Interpretative Structural Modeling (ISM), Islamic Empowerment.

\section{INTRODUCTION}

Disparity of capital access for poor society on banking system is now wider due to the lack of collateral as it is required for a loan. According to World Bank survey in 2010, as quoted in Central Bank of Indonesia's journal in 2011, almost half of 234.2 million of Indonesian people have no access to formal financial banking. Only 35 million of 
them have access to informal financial banking, such as saving and loan cooperative. Nevertheless, there are about 40 million people who have no access at all to any form of financial banking. Another data from World Bank, in Global Financial Inclusian Index 2012, stated that Indonesian people's access to financial banking system is about $20 \%$. It is very low compare to other developing countries.

Contrarily, Indonesia has a lot of microbusiness, but they are not supported with financial banking system in which one of its function is to shape connection between one with capital and one who need capital. Therefore, financial inclusion is needed to narrow the disparity. In another word, it is needed to narrow social disparity and to improve Indonesian people's welfare.

Central Bank of Indonesia's journal 2011 stated that financial inclusion is a universal activity and its function is to overcome all obstacles, in price or nonprice ${ }^{3}$, so the people will be easy to access financial banking system. Radyati (2012) explained, financial inclusion is a condition where everyone has access to financial banking system which is qualified, with low rate, fun, easy, respectful and honorable.

We can implement financial inclusion by strengthening the synergy between bank and nonbank institutions. As a wide range financial institution, we can use bank as fundamental institution specifically in providing capital. On the other hand, we improve nonbank existence, such as microfinance institutions, in reaching out poor group of people and microbusnesses as many as they can.

The important factor is how to reach group of poor people who have no collateral, but they need financial support to improve their lives. One of many formal microfinance that succeed and known worldwide in reaching out group of poor people is Grameen Bank in Bangladesh. Its financial system is now applied in many countries and in Indonesia as well.

This study explains Group Lending Model (GLM) that we implement in association with community group supervised by Tazkia Microfinance Center (TMFC), Babakan Madang, Sentul, and its impact on community's member. This study also confirms the most dominant factor in one variable group with structural equation modeling approach. It also provides solutions in strategy analysis in starting up Islamic GLM to be more effective and efficient. The originality of this research is using three implemented variables and combines all these variables into one model, such as Culture Characteristic, Government Organization, and Effectiveness of GLM program. After constructing the model through the relevant theory, then the model is applied in Group Lending Model as a part discussion from financial inclusion. The solutions and strategy analysis are provided as the main origanility of this research using interpretative structural modeling.

\section{THEORETICAL BASE}

\section{Group Lending Model}

Basically, microfinance consists of two models, formal and nonformal. Formal microfinance shaped by formal finance institutions, such as commercial banks and nonshariah or shariah local community-base banks (BPR/BPRS or BMT). Unfortunately, most of them

\footnotetext{
${ }^{3}$ Nonprice obstacle means administrative conditions that put burden on consumer such as collateral or guarantee (Bank Indonesia, 2011).
} 
are unavailable to poor group of people who have no collateral. In fact, there are so many obstacles, internal or external, involving microfinance institutions (Rusydiana \& Devi, 2013). Nonformal microfinance shaped by group of community with commitment to save and to give loan base only on donor institutions. Most of them are in weak position. The success model of nonformal that can transform into formal model is Grameen Bank (Akanji, 2007).

In some studies, there are terms to describe GLM started by Grameen Bank in Bangladesh, which are group lending, joint liability and social capital. They all have the same meaning which is member of community join together to shape a group so they can save their money and make a loan from it in certain rules they made. They are widely applied in developing countries. Lukman, et., al. (2008) mentioned some microfinance models in several countries, such as Bangladesh with Grameen Bank, Bolivia with Bancosol, African countries with FINCA and ROSCA. All implement joint liability.

Indonesia is also applying the same model promoted by government-own bank, BRI. Rudjito (2003) explained that in 2003 BRI has become the largest microfinance unit in Indonesia. It distributed the largest credit among others ( $\mathrm{Rp} 10.3$ trillion), followed by BPR (Rp 5.1 trillion), dan Pegadaian (mortgage finance, Rp 973 billion). In advance, social capital is a resource that can be viewed as an investment to collect another investment. Vipihindrartin (2008) expressed it because he thinks that resources are everything that meant to consume, to keep or to invest.

The meaning of social capital is quite wide. While human capital means individual experties that can be use to produce something, social capital means many potentials and interpersonal relationship that grow within community or inter-community with specialties in social networks, norms, values, and trusts from inside that can be use to produce something. So we can say that community-base financing, well-known as group lending, is lending money to member of community to make them easy in accessing financial services. Mostly, it is mean for poor group of people who do not have the collateral. It is mean for individual purposes, but all member of community are responsible to repay the credit until due time, daily, weekly or monthly.

The main function of group lending in microfinance view is social aspect of it for beneficiary is bigger than economy aspect. It does not require collateral, but trust. Credit is given to small groups or small businesses (peer pressure) which credible to pay. In Bangladesh, main target of group lending such as Grameen Bank are moslty women because they are considered as more sensitive and reliable when it related to save and loan (Schurmann dan Johnston, 2009).

\section{Determinant Factors of Effectiveness Ratio of Group Lending Model}

Culture is one determinant factor to support economy activities, especially in developing group lending model. According to Fukuyama (2002), good environment and culture are positive factors to individual/community interrelationship. Considering that GLM is a community-base model, we should consider also the character of each community member which is shaped according to the surrounding environment and culture.

To build a good GLM, the character of each individual is not the only factor needed. We have to evaluate relationship among each member in a community. Rai and Sjostrom (2004) stated that in evaluating the effeciency of GLM, one member helping others is not enough. Cross reporting among member in a community is required as a report to the bank. Every 
member should do: monitoring, observing and evaluating other member. This kind of intensive and non-confronting proccess can not be pursuit by bank.

Penalty in form of social sanction is another factor that determine the success of GLM. According to Besley and Coate (1995), social sanction means good repayment in GLM scheme. If social sanction works well, payment works well too.

Greenberg, et. al. (1999) wrote, the success of lending group can be determine base on:

(1) solidarity and loyalty to the community

(2) participation of each member in making policies

(3) commitment of each member to every policies

(4) mutual trust among member in community

(5) good intention to uphold every policies.

In the other hand, the government has an important role in helping GLM keeps on its track. Ridwan (2012) stated, community welfare, substantially, affected by external factors, such as surrounding environment and government intervention, and internal factors, such as in demographic: education level, ability to work, motivation to work, effectiveness to work, experience to work, and individual character.

\section{Previous Studies}

Aghion dan Morduch (2005) stated that GLM is a successful financing model in microfinance. GLM also emphasizes several aspects in microfinance, for instance dynamic repayment, durability in repayment and public cooperation in repayment. In several microfinance scheme, the durability payment is schedule for daily, weekly to monthly. Meeting among lenders and supervisor of GLM helds regularly so the loan officers can get information from lenders about their problems in running businesses and they will try ro work it out together.

Kono (2007) was conducting field case study in Vietnam to understand the work of GLM in monitoring, cross reporting, social sanction upholding on moral hazard, communication among individuals and individual grouping base on lending and payment return. He found that GLM contracts between lenders and microfinancing institution cause serious problems in strategic failure and low rate in repayment.

Different case is found in Viphindrartin (2012) field case study. He mapped his study into three basic community culture: Matraman, Arek and Madura in order to allow him to see the connection and influence of GLM effectiveness. He put social relation that reflects from each culture group as fundament to shape social capital group. This hopefully can stimulate repayment rate and program effetiveness. His study showed, culture characteristic and social capital in certain community give positive effects to the beneficiaries in repayment and reflect effectiveness of GLM program in elevating poor rate.

\section{Hypothesis}

The following are research hypothetical made based on the objective and the research model: $\mathrm{H} 1=$ Culture Characteristic has a significant effect on Government Organization $\mathrm{H} 2=$ Culture Characteristic has a significant effect on Effectiveness of GLM Program $\mathrm{H} 2=$ Government Organization has a significant effect on Effectiveness of GLM Program 


\section{METHODOLOGY}

The types of this research are qualitative and quantitative studies. Researchers conducted this research using primary and secondary data. Primary data is data obtained directly through various methods, such as questionnaires and interviews. While secondary data is data obtained from the study of literature supporting. The questionnaire used in this study using a close-ended question, shaped Likert scale and vaxo, the scale of assessments requires respondents to indicate the level of agreement or disagreement with any kind of statement about the object of the stimulus.

In order to confirm the model which is constructed in this study, the population was all members of Group Lending Model supervised by Tazkia Microfinance Center, Babakan Madang, Sentul, it's about 2032 members. Selection of the samples in this study used a nonprobability sampling techniques with the total samples are 150 respondents. In order to identify the solutions and strategies using Interpretative Structural Modeling, selection of the samples also used a non probability sampling (purposive sampling) with the numbers of informant are 7 informants who really expertise in this subject.

There are two analysis techniques were used in this study:

1. Confirmatory Factor Analysis (CFA). CFA used to confirm the most priority (dominant) factors in one variable group and Regression weight. CFA also used in the SEM study to identify the coefficient value of the causality relationship among variables.

2. Interpretative Structural Modeling (ISM). ISM used to analyze the strategies to enhance the Islamic GLM in order to be more effective and efficient. But in this paper, the analysis result of ISM would be discussed only decomposition studies.

In order to find the answer from the first research question, this study will describe the position of each variable and also the relationship among variables. There are three variables used in this study, one of them is independent variables and two of them are dependent variables. Independent variables consist of culture characteristic, and dependent variables consist of government organization and Effectiveness of GLM program. To answer this causality study, we use quantitative approach by using survey method (questionnaire) are distributed to 100 experts. The data analyzed by using Structural Equation Modeling (SEM) to identify the relationship among variables. Operational definition and the indicator used for each variables, will be described in the table below. 
Table 1: Variable Operational Definition and Indicators

\begin{tabular}{|c|c|c|c|}
\hline Variable & $\begin{array}{c}\text { Variables Operational } \\
\text { Definition } \\
\end{array}$ & Indicators & $\begin{array}{c}\text { Indicators Operational } \\
\text { Definition } \\
\end{array}$ \\
\hline $\begin{array}{c}\text { Culture } \\
\text { Characteristic }\end{array}$ & $\begin{array}{l}\text { Culture is one of the } \\
\text { factors which will } \\
\text { support society economic } \\
\text { activity, especially to } \\
\text { enhance group lending } \\
\text { model program (GLM). } \\
\text { A good environment } \\
\text { and culture will affect to } \\
\text { the individuals behavior } \\
\text { to do the muamalah } \\
\text { (Fukuyama, 2002). }\end{array}$ & $\begin{array}{l}\text { X1 (Group Potential) } \\
\text { X2 (Relationship Behavior } \\
\quad \text { among member group) } \\
\text { X3 (Teamwork) } \\
\text { X4 (Value/norm) } \\
\text { X5 (Relationship) }\end{array}$ & $\begin{array}{l}\text { These five indicators are measured } \\
\text { by seeing the capability of each } \\
\text { individual in one group, trust } \\
\text { relationship, (tanggungrenteng), } \\
\text { the role of customs and community } \\
\text { figures, in common areas, living } \\
\text { environment, occupation, etc }\end{array}$ \\
\hline $\begin{array}{l}\text { Government } \\
\text { Organization }\end{array}$ & $\begin{array}{l}\text { The government or } \\
\text { organization which is } \\
\text { regulating GLM program } \\
\text { and also supporting the } \\
\text { GLM activity program. }\end{array}$ & $\begin{array}{l}\text { Y1 (Government Regulation) } \\
\text { Y2 (Facility Supporting dan } \\
\text { Monitoring) } \\
\text { Y3 (Assistance and Coaching) } \\
\text { Y4 (Financial Capital Support) } \\
\text { Y5 (Program Socialization) }\end{array}$ & $\begin{array}{l}\text { These five indicators are measured } \\
\text { by seeing the regulation related } \\
\text { to GLM. Whether the GLM has } \\
\text { been fulfilled the need of society } \\
\text { or not, and also by seeing the } \\
\text { role of government especially in } \\
\text { supervision and counseling. }\end{array}$ \\
\hline $\begin{array}{c}\text { Effectiveness } \\
\text { of GLM } \\
\text { program }\end{array}$ & $\begin{array}{l}\text { Effectiveness of GLM } \\
\text { Program was described } \\
\text { through the condition and } \\
\text { lending group society } \\
\text { behavior (the recipients } \\
\text { of the fund from this } \\
\text { program). }\end{array}$ & $\begin{array}{l}\text { Z1 (Society Participant) } \\
\text { Z2 (Society Productivity) } \\
\text { Z3 (Good Repayment rate) } \\
\text { Z4 (Good Cross Reporting) } \\
\text { Z5 (Penalty) }\end{array}$ & $\begin{array}{l}\text { These five indicators are measured } \\
\text { by seeing the community } \\
\text { participant in GLM program, } \\
\text { and also by seeing the difference } \\
\text { of community economic social } \\
\text { condition before and after } \\
\text { following the program. Repayment } \\
\text { rate, cross reporting, and penalty } \\
\text { also being measurement to } \\
\text { identify the effectiveness of GLM } \\
\text { program. }\end{array}$ \\
\hline
\end{tabular}

Data analysis method used in this study is Structural Equation Modelling (SEM). SEM is used to analyze the research model, identify the dimensions from each construct, and to measure the effect/relationship among factors and dimensions (Ferdinand, 2006). Superiority from this method is SEM has capability to confirm the dimensions from a concept of factors and the capability to measure the effect of the relationship based on the theoretical concepts. In the SEM model, there are some steps of research:

1. Theoretical model development.

The first step is to develop SEM model. SEM model development must be supported by strong theoretical concept. Theoretical concept would be found through literature review from the journal that relates to the model developed.

2. Path Diagram Development. Path Diagram developed to show the causality relationship among variables. Research model which has been developed in the first step will be described in a path diagram. Path diagram would ease to see the causality relationship among variables tested. The constructs in path diagram could be divided into two groups:

- Exogenous Construct, or source variable or independent variable.

- Endogenous Construct or dependent variable. 
Path diagram developed for this study, as follows:

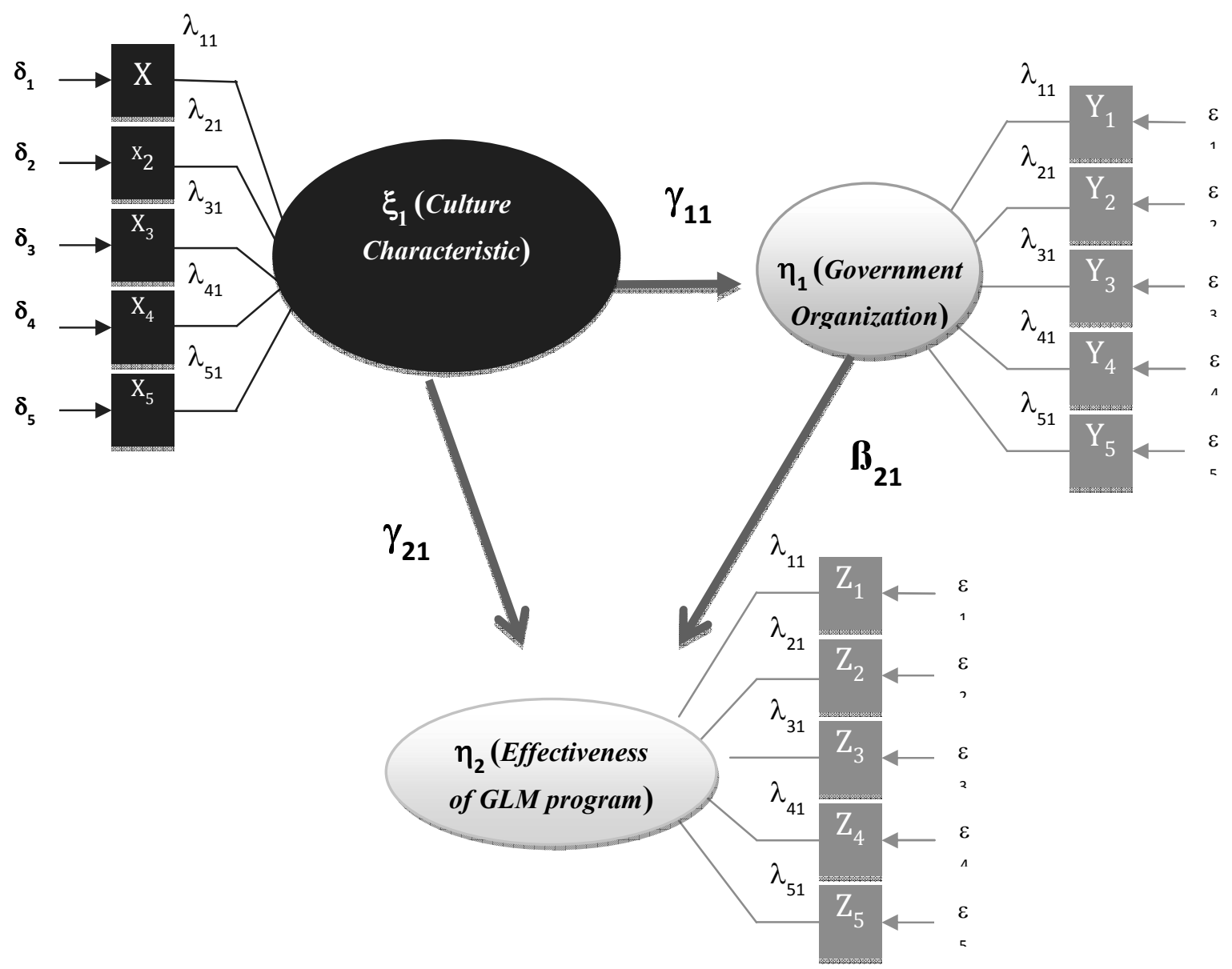

Figure 1: Hybrid Measurement Model

3. Path diagram conversion to structural equation and measurement model specification

4. Input matrix selection and estimation technique

Data input of SEM is using matrix/covariance or correlation matrix to overall estimation. Covariance matrix used in order to provide valid comparison between difference population and difference sample which can not provided by correlation. According to Heir, et al theory, suggests to use appropriate sample from 100 to 200 respondents. Minimum sample for SEM study is 5 respondent for each parameter estimated.

5. Identifying identification problem.

Identification problem is incapability of the developed model to find the unit estimation. One of the solutions from identification problem is to give more constraint to the analyzed model and it means to eliminate the number of estimated coefficient. If every estimation have identification problem, then, the model constructed must be developed (based on the available theory/eliminating or creating more construct).

6. Goodness of fit criteria evaluation.

Goodness of fit criteria by doing the test of the model according to appropriate goodness of fit criteria. Means that the data has been fulfilled all of SEM assumption. 
Second data analysis method used in this study is Interpretative Structural Modeling (ISM). ISM is a decision making method took from the complexity situation by correlating and organizing the idea into the visual map. ISM basic concept is using expert and practitioners to generate complexity system into some sub system (element) and build a hierarchy structural modeling. ISM also used to give the basic understanding from the complexity situation, and arranging the strategy to solve the problems (Gorvett and Liu, 2007).

There are some step to analyze ISM method, first stage is problem decomposition to the expert or practitioners (who has better understanding related to the problem discussed/ brainstorming) to identify the ideas of the organization development, has better understanding about GLM model development problem and has the skill in microfinance and empowerment studies. From this discussion, will be explored the development strategies, and the variables used in ISM model. Second stage is constructing Structural Self Interaction Matrix (SSIM) model. SSIM is constructed from the variables founded from decomposition step, then develop the contextual relationship among variables and gathering into one variable $i$ and variable $j$. Third stage is creating reachability matrix $(\mathrm{RM})$ by conversing the $\mathrm{V}, \mathrm{A}, \mathrm{X}$, and $\mathrm{O}$ used into the numbers 1 and 0 . Forth stage is creating canonical matrix to identify the level through the iteration. If the intersection is not found anymore, next step is creating the model resulted from the ISM software. The model resulted used to solve the problem (in this study: GLM model development problem). From the model also explored the road map of organization development (level).

\section{RESULT AND ANALYSIS}

\section{Model Analysis}

Base on statistic analysis from SEM data and what found in field case study, we know that certain culture characteristic can influence community in the success of GLM program. On the contrarary, government and organization factors can not be determined as effective factor for the program.

In sorting phase through SEM experiment, base on indicator of loading point $\leq 3,00$ (Wijanto, 2008), last model in this study have three laten variable:

1. laten variable of $X$ (culture characteristic) with three indicators observed

2. laten variable of Y (government/organization) with four indicators observed

3. laten variable of $Z$ (effectiveness of GLM program) with five indicators observed (see at subchapter in methodology)

At first phase of model analysis, we validated data to see its reliabilities by looking at t-point contained factor. We consider a variable has a good validity if its t-point contained factor more than critical point of 1.96 (Ridgon and Ferguson in Wijanto, 2008). Estimated result t-point contained factor for the first model can be seen in picture 2 . 


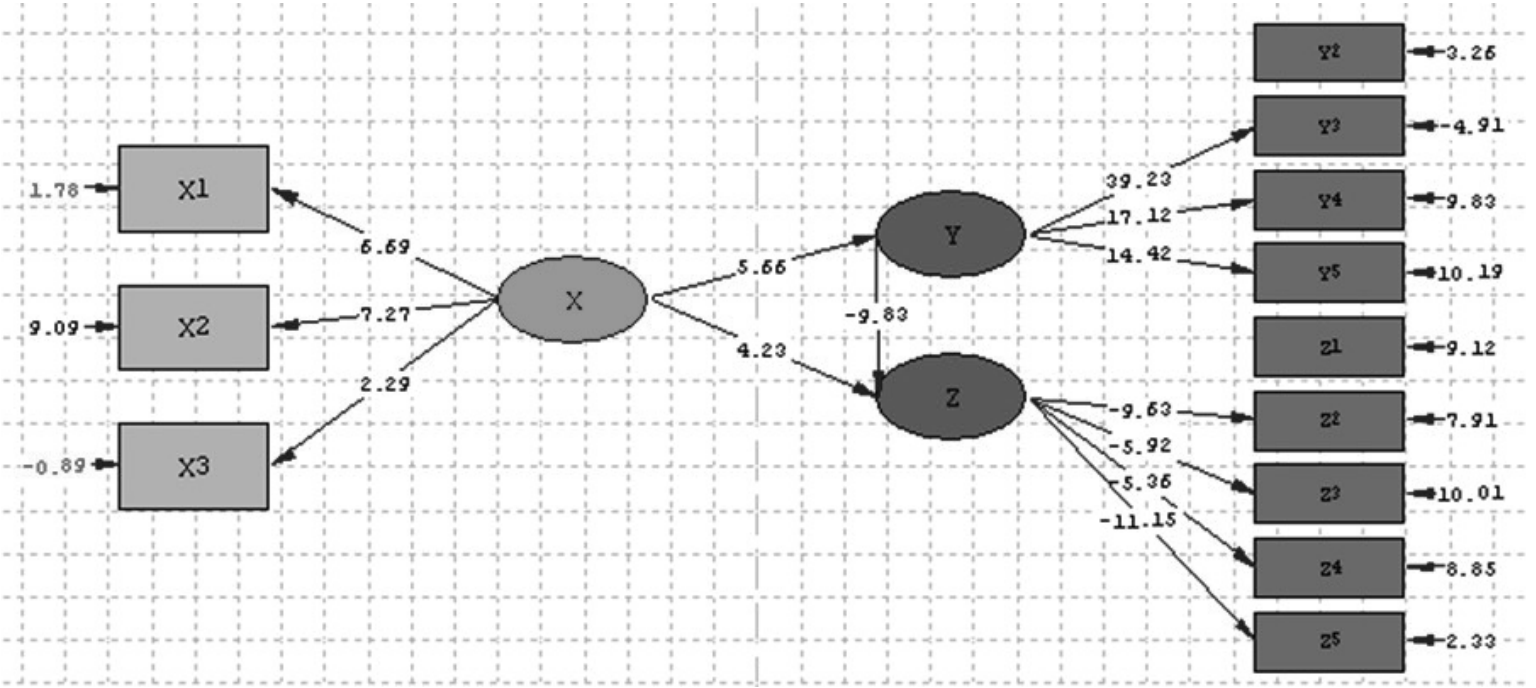

Figure 2: t-value

Figure 2 shows diagram of complete GLM model line with numbers that show t-point from each related estimated result. Point showed more than 1.96 indicates significancy at 5\%. It tells us that the whole indicators have a good validity in explaining its laten variable because all of them shows t-point more than critical point 1.96.

Reliability model can be measured with equation of construct reliability (CR) and variance extracted (VE) base on standard contained factor and error in diagram of GLM which can be seen in picture 3 below.

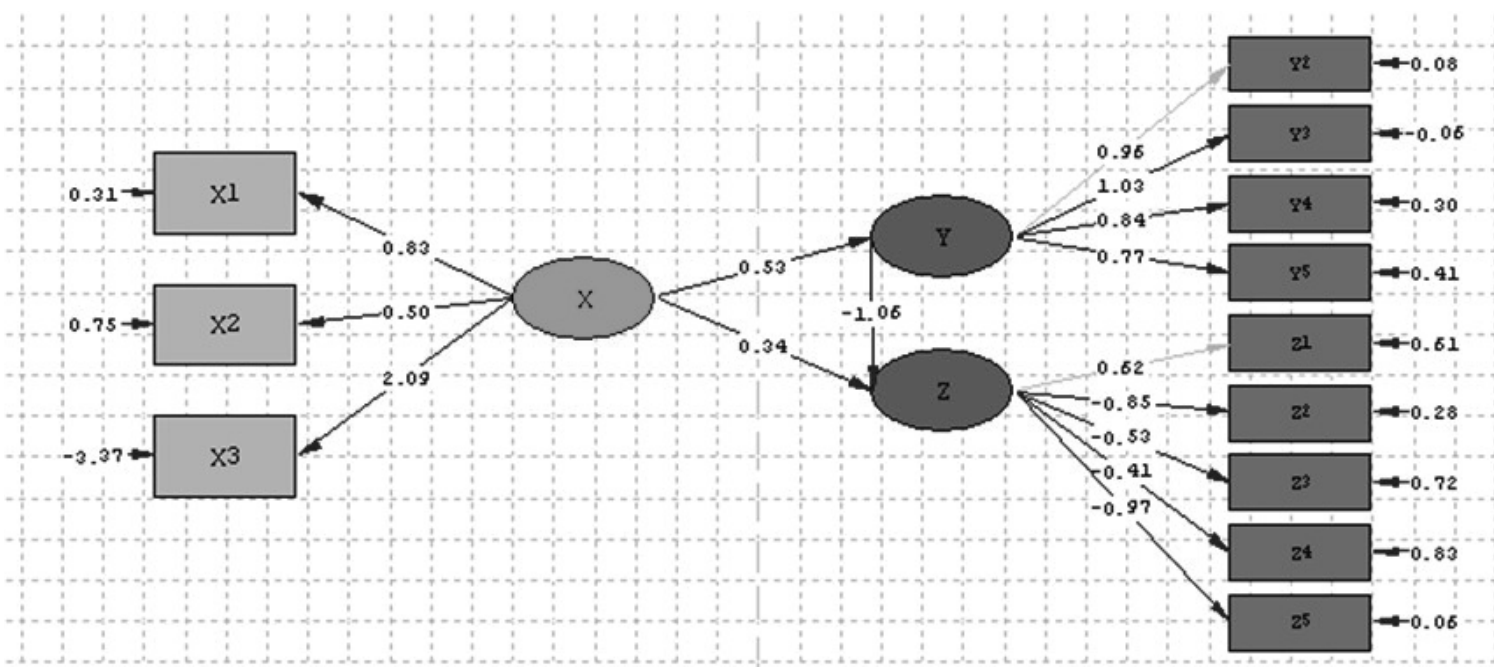

Figure 3: Standardized Solution

From figure 3, we found that reliability data from CR and VE can be seen. High reliabillity indicates the indicators have high consistency in measuring its laten contruction (Wijanto, 2008). We see, the conclusion from validity and CR EV measurement of GLM effectiveness can be observed on table 2 as followed. 
Table 2: GLM Validity and Reliability Test

\begin{tabular}{|c|c|c|}
\hline & \multicolumn{3}{|c|}{ SUMMARY } \\
\hline & \multicolumn{2}{|c|}{ Reliability } \\
\hline Variable & $\mathbf{C R} \geq \mathbf{0 . 7}$ & VE $\geq \mathbf{0 . 5 0}$ \\
\hline $\mathbf{X}$ & $1.25 \geq 0.7$ & $1.77 \geq 0.50$ \\
\hline $\mathbf{Y}$ & $0.93 \geq 0.7$ & $0.79 \geq 0.50$ \\
\hline $\mathbf{Z}$ & $0.70 \geq 0.7$ & $0.50 \geq 0.50$ \\
\hline
\end{tabular}

Reliability of GLM considered as good if construct reliability $(\mathrm{CR}) \geq 0,70$ and variance extract $(\mathrm{VE}) \geq 0.50$. Coefficient point of $\mathrm{CR}$ and $\mathrm{VE}$ for laten variable of $\mathrm{X}, \mathrm{Y}$ and $\mathrm{Z}$ has already qualified. We can say that indicators on reliable laten variable with extraction ability represent construction above conditioned point.

The next phase is analyzing criteria goodness of fit. Several analysis can be conducted on points in GLM model to identify goodness of fit. A GLM model considered as a good and valid model if it fulfills absolute and incremental fit which can be summarized in following table.

Table 3: Parameter and Result of Goodness of Fit for All GLM Model

\begin{tabular}{|c|c|c|c|}
\hline $\begin{array}{c}\text { GoF } \\
\text { Measurement }\end{array}$ & Level of Fit & Estimation result & Degree of Fit \\
\hline Chi-Square P & Little value of P $\geq 0.05$ & 0.00000 & Marginal fit \\
\hline Normed chi-square & Lower $(0.1)$-Upper $(0.5)$ & 2.041 & Good fit \\
\hline SNCP & Smaller better & 1.74 & - \\
\hline NFI & NFI $\geq 0.90$ & 0.94 & Good fit \\
\hline NNFI & NNFI $\geq 0.90$ & 0.81 & Mariginal fit \\
\hline CFI & CFI $\geq 0.90$ & 0.94 & Good fit \\
\hline IFI & IFI $\geq 0.90$ & 0.94 & Good fit \\
\hline GFI & GFI $\geq 0.90$ & 0.87 & Marginal fit \\
\hline
\end{tabular}

Model that shaped in this analysis has chi-square point 132.60 with degree of freedom (DF) as 20 and $p$-value as 0.0000 which lesser than 0.05 . Normal point for chi-square is between lowest level and highest level, which is 2.041. With 2.041, a model considered as a good in goodness of fit. SNCP point obtained should be 1.74 to compare with next model. Other point that obtained from goodness of fit criteria are NFI, CFI and IFI. They all showed point above expected point, $\geq 0.9$, and considered as good fit. We can say that GLM model base on this study considered as a good model (Browne and Cudeck in Wijanto, 2008).

\section{Hypothetical Analysis}

In general, SEM model in picture 3 gives us hypothetical prove how culture characteristic influences government/organization factors and culture characteristic variable and govrnment/ organization influences effectiveness. All three relations can be seen in next picture. 

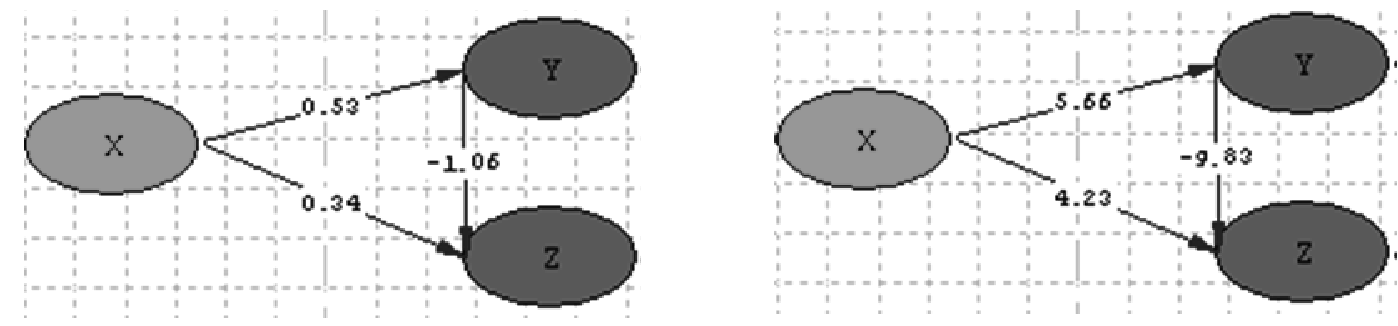

Figure 4: Structural-Value Standardized Solution dan T-value Model

According to t-value obtained in figure 4, laten variable of $X$ gives positive influence to $\mathrm{Y}$ and $\mathrm{Z}$ which reflects on individual responsibilities. Laten variable of $\mathrm{Y}$ gives negative influence to $Z$. Evaluation base on picture 3 can be summarized in table 3 with hypothetical analysis from field case study.

Table 4: Coefficient of Structural Model and Its Relation to Hypothesis of Study

\begin{tabular}{|c|c|c|c|c|}
\hline Hypo-thesis & Path & SLF $\geq 0.30$ & t-value $\geq 1.96$ & Conclusion \\
\hline 1 & $\begin{array}{c}\text { Culture characteristic (X) } \Rightarrow \\
\text { Organization /government (Y) }\end{array}$ & 0.53 & 5.66 & $\begin{array}{c}\text { Significant } \\
\text { (hypothesis accepted) }\end{array}$ \\
\hline 2 & $\begin{array}{c}\text { Culture characteristic (X) } \Rightarrow \\
\text { effectivity of GLM program (Z) }\end{array}$ & 0.34 & 4.23 & $\begin{array}{c}\text { Significant } \\
\text { (hypothesis accepted) }\end{array}$ \\
\hline 3 & $\begin{array}{c}\text { Organization/ government (Y) } \Rightarrow \\
\text { effectivity of GLM program (Z) }\end{array}$ & -1.06 & -9.83 & $\begin{array}{c}\text { Significant } \\
\text { (hypothesis accepted) }\end{array}$ \\
\hline
\end{tabular}

From table 4, we see that culture characteristic variable's relation to government/ organization has t-point contained factor as 5.66. This point is above 1.96. It means, the relation is significant and has positive coefficient. It indicates positive realtionship between these two variables. Culture characteristic variable gives strong influence $(0=$ very weak influence; $1=$ very strong influence).

\section{Development Strategy}

Next analysis is strategic study which allow us to develop GLM through interpretative structural model. It comes from depth interview with competence experts. Next phase, we can obtain structural model for certain purposes as seen in picture 5. There are, at least, seven levels of certain purposes from structural model consist of nine elements:

1. Fair Access Fund (to all kind financial institution, banking or nonbanking)

2. Improve Human Resources Quality

3. Inclusion in Financial System

4. APEX Institution

5. GLM Rating System

6. Technical Assistant

7. Government Support

8. Fair Competition Act and

9. Economic Stability 


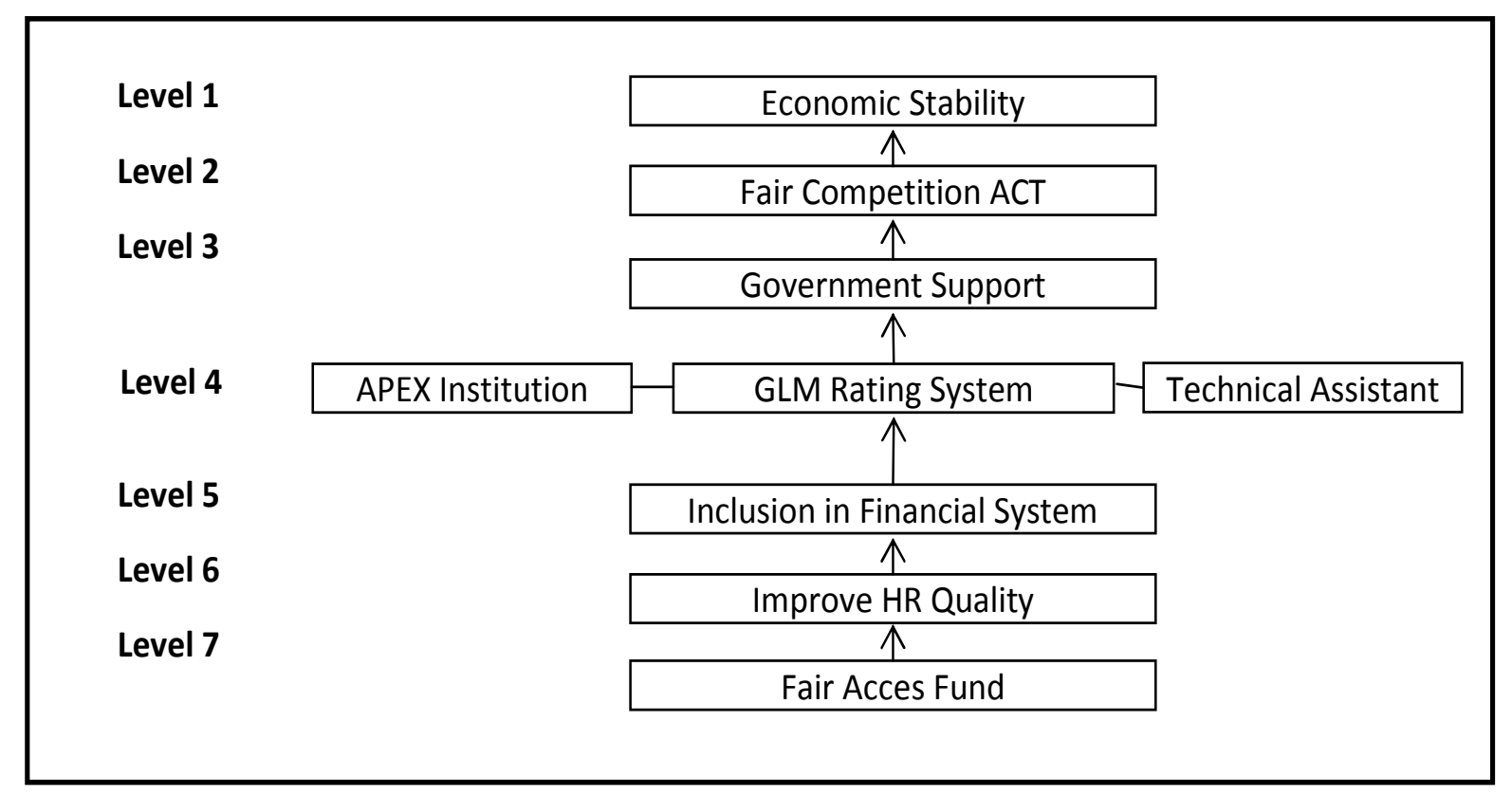

Figure 5: Structural Model for Certain Purposes

Fair access of fund element becomes the most important thing as fundament to GLM purposes followed by improving human resources quality element as pioneer to GLM service model, then inclusion in financial system element. As for the next four elements, there are three elements which is the same important as others in developing GLM system: APEX institution, GLM rating system, and technical assistant. Next are government support, fair competition act and economic stability. Eventhough, those elements should be considered as a whole strategy in order to get comprehensive result.

\section{CONCLUSION AND RECOMMENDATION}

In general, GLM is shaped by involving community with the same geographic condition and culture. These similarities contribute good conditions in save and loan activities. Culture factor measured by using group potential indicators, interindividual relationship pattern, cooperative pattern, and values/norms from tradition or religion. Each of them has their own measurement aspects such as in interindividual relationship pattern (knowing one to another, trust and similarity in daily activities). In other words, a good culture characteristic of community contributes a positive attitude and understanding from government in encouraging GLM to perform as it should be.

Field case study indicated that members of GLM benefeciary have a good cooperative relationship with GLM. It is shown in their regular meeting gathering held by GLM. They also have discipline and problem solving ability through understanding among them. This condusive conditions will increase government trust and spirit to support GLM in making regulation/policy or in investing money. Vipihindrartin (2012) mentioned in his study, government has important role in social capital as policy maker, fasilitator or supervisor. It means government should maximize its role through non-government organization (LSM) to supervise, to fasilitate, to make policy and to fulfill group of lender's need. 
Culture characteristic is also a positive influence to effectiveness ratio of GLM. It reflects from community responsibility to repayment their credit. We measure culture characteristic by looking at their participation, empowerment, repayment ratio, cross reporting and penalty upholding as they agreed. At the end, community senses the difference in their economic and social life. Their lives improve since they join GLM. They become more prosperous than ever. They economic activities varies and growing well. Kono (2007) said, good repayment ratio and cross reporting indicates social capital effectiveness. Trust among member of community, religious environment and dynamic environment morally and spiritually can minimize capital deviance by GLM member. It minimizes moral hazard among in theirselves [Stiglitz (1990), Varian (1990), Banerjee, Besley adn Guinnane (1994)].

In contrast, government/organization role is a negative influence to effectiveness ratio of GLM. Field case study discovered, member of community who join GLM do not see goevernment/organization role directly influence their lives, especially in fasilities or investment. Both are main aspects for GLM to run its programs. On the other hand, member of community who join GLM do not understand the mechanism and system of GLM. This lack of information probably caused by the lack of government action to socialize GLM. Vipihindrartin (20012) mentioned, government action is merely a formal action. This leaves so many member of community who do not understand the important of GLM through microcredit. It is time for OJK (Finance Services Authority) to take more part in monitoring and regulating financing program by banks or nonbanks.

Moreover, Setiawan (2012) confirmed that tight regulation and supervision considered as an important factor to minimize risk caused by moral hazard or misdeeds or to avoid private and political interest in public needs. So, we emphasize several GLM developing strategies that succeed to perform microfinance program as we found in field case study:

1. Fair Access Fund (to all kind financial institution, banking or nonbanking)

2. Improve Human Resources Quality

3. Inclusion in Financial System

4. APEX Institution

5. GLM Rating System

6. Technical Assistant

7. Government Support

8. Fair Competition Act and

9. Economic Stability

There are some limitations encountered in this study, first, the variables used in this research are limited, then the suggestions for future research is to add more variables that suspected has significant effect to effectiveness of GLM program. Second, few of references, so future research should be able to explore more resources and references from existing research. Third, less of informant, so future research should be able to add more informant who really expert regarding to this study. Based on the limitations encountered in this study, the following agenda for future research there are add more variables that suspected has significant effect to effectiveness of GLM program, explore more resources and references from existing research and add more informant who really expert regarding to this study. 


\section{REFERENCES:}

Aghion, B. A., \& Morduch, J. (2000). Microfinance Beyond Group Lending. Economics of Transition 8(2), 401-420.

Akanji, O.O. (2007). Micro Finance as A Strategy for Poverty Reduction. CBN Economic and Financial Review, 39(4).

Banerjee, A. V., Besley, T. and Guinnane, T. W. (1994). Thy Neighbor's Keeper: The Design of a Credit Cooperative with Theory and a Test. Quarterly Journal of Economics, 109(2), 491-515.

Ferdinand, A. (2006). Structural Equation Modeling dalam Peneltian Manajemen. Edisi 2, Seri Pustaka Kunci 03/BP UNDIP

Fukuyama, F. (2002). Social Capital and Development: The Coming Agenda. SAIS Review. 22(1) (winter $\mathrm{u} / 2013$ spring 2002)

Gema PKK. (2003). Kemiskinan dan Keuangan Mikro. KPK

Greenberg, E. S., Patricia B. S., Leon G., and Sarah M. (1999). Work Tems and Organizational Commitment: Exploring the Influence of the Team Experience on Employee Attitudes. Workplace Change Project Working Paper WP-012.

Gorvett, R. and Liu, N. (2007). Using interpretive structural modeling to identify and quantify interactive risks. Orlando - USA: ASTIN Colloquium.

Kono, Hisaki. (2007). Is Group Lending A Good Enforcement Scheme for Achieving High Repayment Rates? Evidence form Framed Field Experiments in Vietnam. Academic Research Repository at the Institute of Developing Economies. 1-33.

Lukman, S., Lukviarman H., Rivai, H.A., Husni, T., Syafrizal, \& Maruf (2008). Kajian Upaya Penguatan Peran Microbanking dan Pendekatan Pembiayaan Kelompok dalam Rangka Pengembangan UMK di Sumatra Barat. Penelitian atas kerjasama antara Bank Indonesia dan Center for Banking Research Universitas Andalas. 1-12.

Patten, Richard H, Jay K. Rosengar. (1991). The Development of Rural Banking in Indonesia. San Fransisco: ICS Press.

Radyati, Maria R. Nindita. (2012). Keuangan Inklusif Perbankan. Retrieved from Universitas Trisakti, MMCSR \& MMCE, http://www.mmcrusakti.org

Rai, A. S. and Sjostrom, T. (2004). Is Grameen Lending Efficient? Repayment Incentives and Insurance in Village Economies. Review of Economic Studies, 71, 217-234.

Ridwan, M. (2012). Penguatan Ekonomi Masyarakat Berbasis Kelompok. Jurnal Ekonomi Pembangunan, 13 (2), 207-217.

Rudjito. (2003). Sinergi Kebijakan dalam Mendorong Pertumbuhan Usaha Mikro Kecil dan Menengah. Paper dipresentasikan pada Lokakarya Mendorong Pertumbuhan Usaha Kecil dan Menengah yang Sehat dan Berdaya Saing. Asosiasi Pengusaha Indonesia (APINDO). 
Rusydiana., Slamet, A., and Devi, A. (2013). Challenges in Developing Baitul Maal wat Tamwiil (BMT) in Indonesia using Analytic Network Process (ANP). Business and Management Quarterly Review, 4(2), 51-62.

Rusydiana., Slamet, A. and Devi, A. (2013). Mengurai Masalah dan Solusi Pengembangan Lembaga Keuangan Mikro Syariah (LKMS) di Indonesia: Pendekatan Metode BOCR Analytic Network Process (ANP). Jurnal Ekonomi dan Bisnis Islami, 3(1), 19-40.

Schurmann, Anna T dan Johnston, H. B. (2009). The Group-Lending Model and Social Closure: Microcredit, Exclusion, and Health in Bangladesh. J Health Popul Nutr. 27(4): 518527.

Setiawan, Azis. (2012). OJK dan Masa Depan Industri Keuangan Syariah. SEBI Policy Brief (1) Tahun 1, Februari 2012.

Stiglitz, Joseph E. (1990). Peer Monitoring and Credit Markets. World Bank Economic Review 4(3), 351-366.

Varian, H. R. (1990). Monitoring Agents with Other Agents. Journal of Institutional and Theoretical Economics, 146(1), 153-174.

Viphindrartin, Sebastiana (2012). Model Pendekatan Modal Sosial Kelompok Peminjam untuk Optimalisasi Repayment Rate pada Lembaga Keuangan Mikro Swadaya Masyarakat. Journal of Economy Faculty Jember University.

Wijanto, S. H. (2008). Structural Equation Modelling; Konsep dan Tutorial. Yogyakarta: Graha Ilmu. 